\title{
Diamondback Moth, Plutella xylostella (Linnaeus) (Insecta: Lepidoptera: Plutellidae) ${ }^{1}$
}

J. L. Capinera ${ }^{2}$

\section{Distribution}

The diamondback moth is probably of European origin but is now found throughout the Americas and in Europe, Southeast Asia, Australia, and New Zealand. It was first observed in North America in 1854, in Illinois, but had spread to Florida and the Rocky Mountains by 1883, and was reported from British Columbia by 1905. In North America, diamondback moth is now recorded everywhere that cabbage is grown. However, it is highly dispersive, and is often found in areas where it cannot successfully overwinter, including most of Canada.

\section{Life Cycle}

Total development time from the egg to pupal stage averages 25 to 30 days, depending on weather, with a range of about 17 to 51 days. The number of generations varies from four in cold climates such as southern Canada to perhaps eight to 12 in the south. Overwintering survival is positively correlated with the abundance of snowfall in northern climates.

\section{Description}

\section{Egg}

Diamondback moth eggs are oval and flattened, and measure $0.44 \mathrm{~mm}$ long and $0.26 \mathrm{~mm}$ wide. Eggs are yellow or pale green in color, and are deposited singly or in small groups of two to eight eggs in depressions on the surface of foliage, or occasionally on other plant parts. Females may deposit 250 to 300 eggs but average total egg production is probably 150 eggs. Development time averages 5.6 days.

\section{Larva}

The diamondback moth has four instars. Average and range of development time is about 4.5 (3-7), 4 (2-7), 4 (2-8), and 5 (2-10) days, respectively. Throughout their development, larvae remain quite small and active. If disturbed, they often wriggle violently, move backward, and spin down from the plant on a strand of silk. Overall length of each instar rarely exceeds $1.7,3.5,7.0$, and $11.2 \mathrm{~mm}$, respectively, for instars 1 through 4 . Mean head capsule widths for these instars are about $0.16,0.25$,

1. This document is EENY-119, one of a series of Featured Creatures from the Entomology and Nematology Department, Florida Cooperative Extension Service, Institute of Food and Agricultural Sciences, University of Florida. Published: January 2000. Revised: May 2000. This document is also available on Featured Creatures Website at http://creatures.ifas.ufl.edu. Please visit the EDIS Website at http://edis.ifas.ufl.edu. Additional information on these organisms, including many color photographs, is available at the Entomology and Nematology Department website at http://entnemdept.ifas.ufl.edu/.

2. J. L. Capinera, professor/chairman, Entomology and Nematology Department, Cooperative Extension Service, Institute of Food and Agricultural Sciences, University of Florida, Gainesville, FL 32611.

The Institute of Food and Agricultural Sciences (IFAS) is an Equal Employment Opportunity - Affirmative Action Employer authorized to provide research, educational information and other services only to individuals and institutions that function without regard to race, creed, color, religion, age, disability, sex, sexual orientation, marital status, national origin, political opinions or affiliations. For information on obtaining other extension publications, contact your county Cooperative Extension Service office. Florida Cooperative Extension Service / Institute of Food and Agricultural Sciences / University of Florida / Larry R. Arrington, Interim Dean 
0.37 , and $0.61 \mathrm{~mm}$. The larval body form tapers at both ends, and a pair of prolegs protrudes from the posterior end, forming a distinctive "V". The larvae are colorless in the first instar, but thereafter are green. The body bears relatively few hairs, which are short in length, and most are marked by the presence of small white patches. There are five pairs of prolegs. Initially, the feeding habit of first instar larvae is leaf mining, although they are so small that the mines are difficult to notice. The larvae emerge from their mines at the conclusion of the first instar, molt beneath the leaf, and thereafter feed on the lower surface of the leaf. Their chewing results in irregular patches of damage, and the upper leaf epidermis is often left intact.

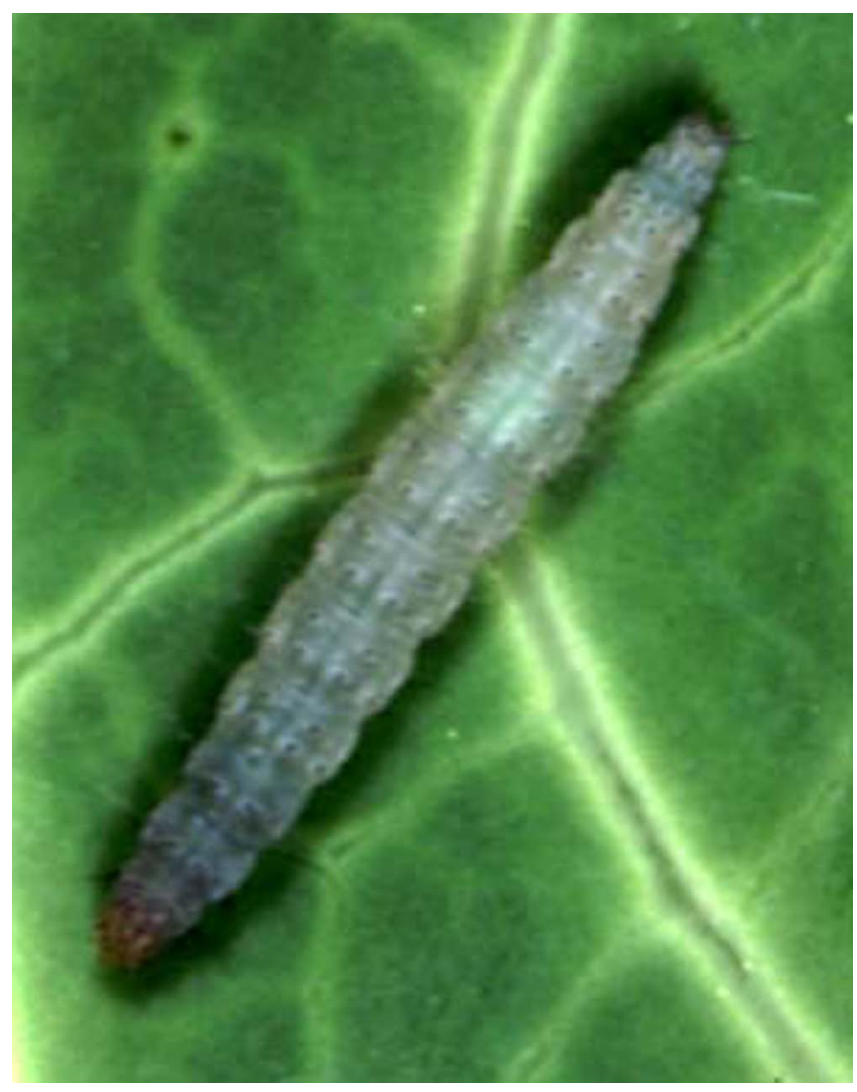

Figure 1. Larva of the diamondback moth, Plutella xylostella (Linnaeus). Credits: James Castner, University of Florida

\section{Pupa}

Pupation occurs in a loose silk cocoon, usually formed on the lower or outer leaves. In cauliflower and broccoli, pupation may occur in the florets. The yellowish pupa is 7 to $9 \mathrm{~mm}$ in length. The duration of the cocoon averages about 8.5 days (range five to 15 days).

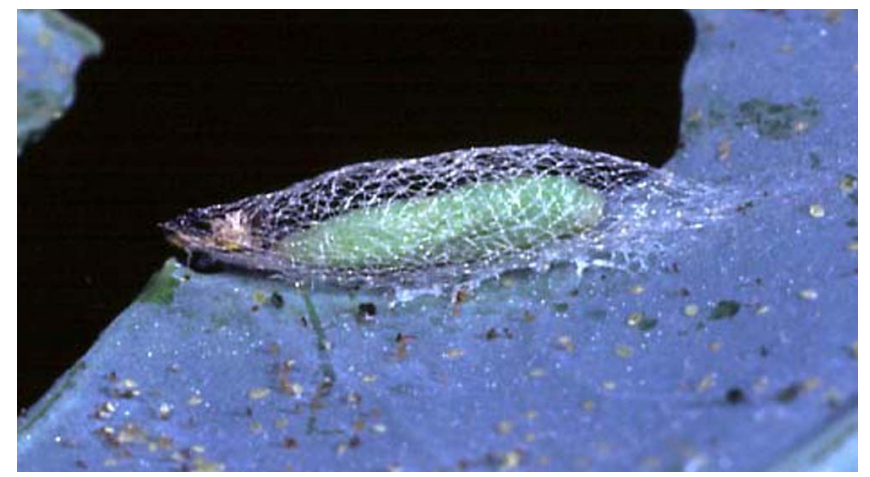

Figure 2. Pupa of the diamondback moth, Plutella xylostella (Linnaeus). Credits: James Castner, University of Florida

\section{Adult}

The adult is a small, slender, grayish-brown moth with pronounced antennae. It is about $6 \mathrm{~mm}$ long, and marked with a broad cream or light brown band along the back. The band is sometimes constricted to form one or more light-colored diamonds on the back, which is the basis for the common name of this insect. When viewed from the side, the tips of the wings can be seen to turn upward slightly. Adult males and females live about 12 and 16 days, respectively, and females deposit eggs for about 10 days. The moths are weak fliers, usually flying within $2 \mathrm{~m}$ of the ground, and not flying long distances. However, they are readily carried by the wind. The adult is the overwintering stage in temperate areas, but moths do not survive cold winters such as is found in most of Canada. They routinely re-invade these areas each spring, evidently aided by southerly winds.

Detailed biology of diamondback moth can be found in Marsh (1917) and Harcourt (1955, 1957, 1963). A survey of the world literature was published by Talekar et al. (1985).

\section{Host Plants}

Diamondback moth attacks only plants in the family Cruciferae. Virtually all cruciferous vegetable crops are eaten, including broccoli, Brussels sprouts, cabbage, Chinese cabbage, cauliflower, collard, kale, kohlrabi, mustard, radish, turnip, and watercress. Not all are equally preferred, however, and collard will usually be chosen by ovipositing moths relative to cabbage. Several cruciferous weeds are important 


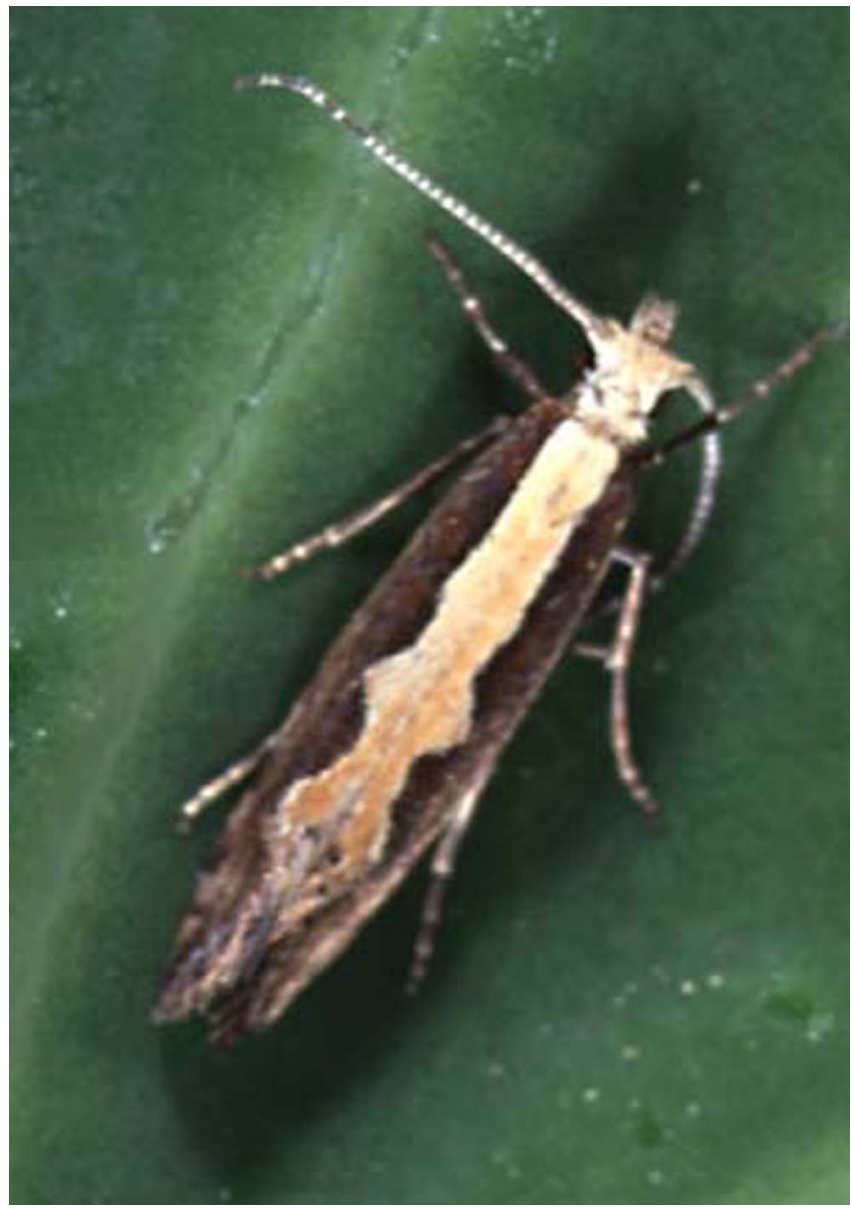

Figure 3. Adult diamondback moth, Plutella xylostella (Linnaeus). Credits: James Castner, University of Florida

hosts, especially early in the season before cultivated crops are available.

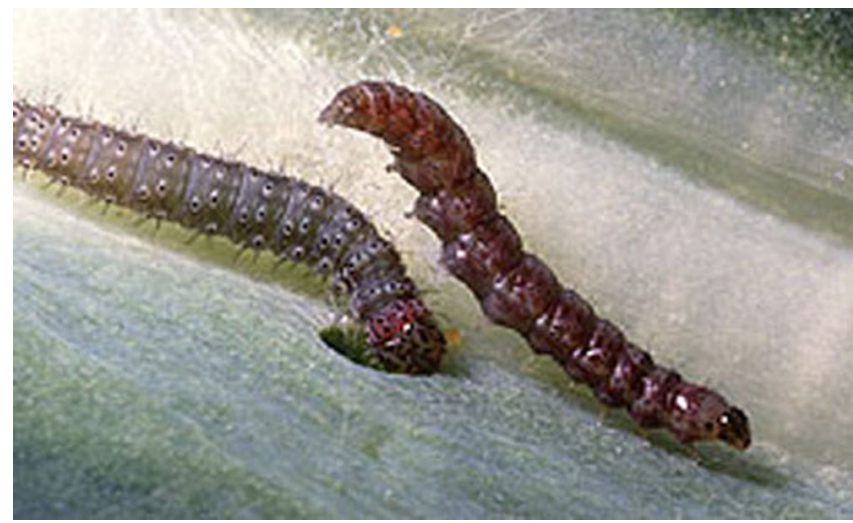

Figure 4. Larvae of the diamondback moth, Plutella xylostella (Linnaeus), feeding on a cabbage leaf. Credits: Doug Wilson, USDA

\section{Damage}

Plant damage is caused by larval feeding. Although the larvae are very small, they can be quite numerous, resulting in complete removal of foliar tissue except for the leaf veins. This is particularly damaging to seedlings, and may disrupt head formation in cabbage, broccoli, and cauliflower. The presence of larvae in florets can result in complete rejection of produce, even if the level of plant tissue removal is insignificant.

Diamondback moth was long considered a relatively insignificant pest. Its impact was overshadowed by such serious defoliators as imported cabbageworm, Pieris rapae (Linnaeus), and cabbage looper, Trichoplusia ni (Hubner). However, in the 1950s the general level of abundance began to increase, and by the 1970s it became troublesome to crucifers in some areas. Insecticide resistance was long suspected to be a component of the problem. This was confirmed in the 1980s as pyrethroid insecticides began to fail, and soon thereafter virtually all insecticides were ineffective. Relaxation of insecticide use, and particularly elimination of pyrethroid use, can return diamondback moth to minor pest status by favoring survival of parasitoids.

\section{Natural Enemies}

Large larvae, prepupae, and pupae are often killed by the parasitoids Microplitis plutellae (Muesbeck) (Hymenoptera: Braconidae), Diadegma insulare (Cresson) (Hymenoptera: Ichneumonidae), and Diadromus subtilicornis (Gravenhorst) (Hymenoptera: Ichneumonidae). All are specific on $P$. xylostella. Nectar produced by wildflowers is important in determining parasitism rates by $D$. insulare. Egg parasites are unknown. Fungi, granulosis virus, and nuclear polyhedrosis virus sometimes occur in high density diamondback moth larval populations.

\section{Weather}

A large proportion of young larvae are often killed by rainfall. However, the most important factor determining population trends is thought to be adult mortality. Adult survival was thought to be principally a function of weather, although this hypothesis has not been examined rigorously. 


\section{Management}

\section{Sampling}

Populations are usually monitored by making counts of larvae, or by the level of damage. In Texas, average population densities of up to 0.3 larvae per plant are considered to be below the treatment level. In Florida and Georgia, treatment is recommended only when damage equals or exceeds one hole per plant. When growers monitor fields and subscribe to these treatment thresholds rather than trying to prevent any insects or damage from occurring in their fields, considerably fewer insecticide applications are needed to produce a satisfactory crop. A minimum plant sample size of 40 to 50 is recommended except for the egg stage, where 150 plants should be examined for accurate population estimates.

Pheromone traps can be used to monitor adult populations, and may predict larval populations 11 to 21 days later. However, because of variation among locations, each crop field requires independent.

\section{Insecticides}

Protection of crucifer crops from damage often requires application of insecticide to plant foliage, sometimes as frequently as twice per week. However, resistance to insecticides is widespread, and includes most classes of insecticides including some Bacillus thuringiensis products. Rotation of insecticide classes is recommended, and the use of B. thuringiensis is considered especially important because it favors survival of parasitoids. Even B. thuringiensis products should be rotated, and current recommendations generally suggest alternating the kurstaki and aizawa strains because resistance to these microbial insecticides occurs in some locations. Mixtures of chemical insecticides, or chemicals and microbials, are often recommended for diamondback moth control. This is due partly to the widespread occurrence of resistance, but also because pest complexes often plague crucifer crops, and the insects vary in susceptibility to individual insecticides.

For specific insecticide recommendations see:

Insect Management Guide for Cole Crops

\section{Cultural Practices}

Rainfall has been identified as a major mortality factor for young larvae, so it is not surprising that crucifer crops with overhead sprinkle irrigation tend to have fewer diamondback moth larvae than drip or furrow-irrigated crops. Best results were obtained with daily evening applications.

Crop diversity can influence abundance of diamondback moth. Larvae generally are fewer in number, and more heavily parasitized, when crucifer crops are interplanted with another crop or when weeds are present. This does not necessarily lead to reduction in damage, however. Surrounding cabbage crops with two or more rows of more preferred hosts such as collard and mustard can delay or prevent the dispersal of diamondback moth into cabbage crops.

Crucifer transplants are often shipped long distances prior to planting, and diamondback moth may be included with the transplants. In the United States, many transplants are produced in the southern states, and then moved north as weather allows. Cryptic insects such as young diamondback moth larvae are sometimes transported, and inoculated in this manner. The transport of insecticide-resistant populations also may occur. Every effort should be made to assure that transplants are free of insects prior to planting.

\section{Host Plant Resistance}

Crucifer crops differ somewhat in their susceptibility to attack by diamondback moth. Mustard, turnip, and kohlrabi are among the more resistant crucifers, but resistance is not as pronounced as it is for imported cabbageworm and cabbage looper. Varieties also differ in susceptibility to damage by diamondback moth, and a major component of this resistance is the presence of leaf wax. Glossy varieties, lacking the normal waxy bloom and therefore green rather than grayish green, are somewhat resistant to larval. Larvae apparently spend more time searching, and less time feeding, on glossy varieties. Glossy varieties also tend to have fewer imported cabbageworm larvae and cabbage aphids, but more cabbage flea beetles. 


\section{Selected References}

Capinera, J.L. 2001. Handbook of Vegetable Pests. Academic Press, San Diego. 729pp.

Cartwright, B., J.V. Edelson, and C. Chambers. 1987. Composite action thresholds for the control of lepidopterous pests on fresh-market cabbage in the lower Rio Grande Valley of Texas. Journal of Economic Entomology 80:175-181.

Harcourt, D.G. 1955. Biology of the diamondback moth, Plutella maculipennis (Curt.) (Lepidoptera: Plutellidae), in eastern Ontario. Rpt. Quebec Soc. Prot. Plants. 37:155-160.

Harcourt, D.G. 1957. Biology of the diamondback moth, Plutella maculipennis (Curt.) (Lepidoptera: Plutellidae), in Eastern Ontario. II. Life-history, behaviour, and host relationships. Canadian Entomologist 89:554-564.

Harcourt, D.G. 1963. Major mortality factors in the population dynamics of the diamondback moth, Plutella maculipennis (Curt.) (Lepidoptera: Plutellidae). Memoirs of the Entomological Society of Canada. 32:55-66.

Marsh, H.O. 1917. Life history of Plutella maculipennis, the diamond-back moth. Journal of Apicultural Research 10:1-10.

McHugh, Jr., J.J. and R.E. Foster. 1995. Reduction of diamondback moth (Lepidoptera: Plutellidae) infestation in head cabbage by overhead irrigation. Journal of Economic Entomology 88:162-168.

Mitchell, E., et al. Biological Control employing natural enemies. USDA. http://www.usda.ufl.edu/biocontrol/natural.htm (February 2000).

Stoner, K.A. 1990. Glossy leaf wax and plant resistance to insects in Brassica oleracea under natural infestation. Environmental Entomology 19:730-739.

Talekar, N.S., H.C. Yang, S.T. Lee, B.S. Chen, and L.Y. Sun (eds.). 1985. Annotated Bibliography of Diamondback Moth. Asian Vegetable Research and Development Center, Taipei, Taiwan. 469 pp.
Workman, R.B., R.B. Chalfant, and D.J. Schuster. 1980. Management of the cabbage looper and diamondback moth on cabbage by using two damage thresholds and five insecticide treatments. Journal of Economic Entomology 73:757-758. 